\title{
Reviews
}

\section{The Art and life of Alàgbà Fálétí - A Pic- torial, Art and Artifacts Exhibition in Honor of Alàgbà Adébáyọ Fálétí (1921- 2017) curated by Akinsola Adejuwon and Seyi Ogunjobi}

\author{
Akinsola Adejuwon \\ Institute of Cultural Studies \\ Obafemi Awolowo University \\ Ile-Ife \\ Nigeria \\ irorun09@gmail.com
}

\section{Introduction}

Alàgbà Adébáyọ Fálétí to generations both in "town and gown" is a Yorùbá iconic cultural statement. His life was a window to different historical epochs in Nigeria. A life that spanned and recorded historical trajectories of early colonial, decolonisation, independent movement, First and Second World Wars, and Nigerian Civil War, Military and Civilian Rules experiences of Nigeria, is worth studying. The Institute of Cultural Studies, Obafemi Awolowo University Ile Ife in recognition of the deep engraving of the footprints of Fáléti in the sands of Yorùbá, indeed African times, called for befitting academic and cultural activities. Among these are this art and artifacts exhibition, a Colloquium, a Playlet and Documentary Film Show. Fálétís intense dedication to the promotion of the Yorùbá omolúàbí cultural ethos and his deployment of his God-given talents and acquired capabilities in the promotion of Yorùbá literary and visual arts, history, poetry, orature, cinema and indeed

1 This is a review of the 2-week pictorial, art and artifacts exhibition in Honor of Alagba Adebayo Faleti in 2017 at the Institute of Cultural Studies, Obafemi Awolowo University, Ile-Ife, Nigeria, curated by Akinsola Adejuwon and Seyi Ogunjobi. 
African arts in general, is not lost on all Fálétí enthusiasts. Furthermore, his remarkable service as Senior Art Fellow at the Institute of Cultural Studies OAU completes the Institute's resolution to capture the worthy legacy in the appropriate location even with the inauguration of an Alàgbà Adébáyọ Fálétí Library, Institute of Cultural Studies. Within a lifetime of close to one century, Fálétí delivers perhaps unique classical Yorùbá messages in words matched with action, first to Africa and then the world.

This review looks at the pictorial and art exhibition covering the world of Alàgbà Adébáyọ Akande Fálétí. It is an assessment of a thematic display of selected pictures and objects which probably placed the observer within the environment and with people Fálétí related with.

The images, pictures, artworks and objects in the display were segmented into five major parts. These focused mainly on Alàgbà Fálétí's parentage, early childhood, education within pristine Yorùbá-driven legacies of the Ọyọ́Yorùbá type, Family life over-written from data flowing from core Yorùbá ethical and artistic 'motherboard.' Represented also are years of adolescence and expressions of early youthful forays under various tutelary influences, variegated working periods, writing and acting plus public service careers. Alàgbà Fálétís childhood coincided with the period when the British Colonial Government had taken over administration of entire geographical space known as Nigeria. In spite of introduction of foreign culture and customs into Nigeria by the Europeans, Yorùbá culture remained resilient. Hence, we could imagine that the childhood of Alàgbà Fálétí was not radically different from Samuel Johnson's description of features of Yorùbá childhood as characterised by 'freedom' (Johnson: 2009, pp.98-100).

These facets of life are arranged in a flow of one hundred and thirty-two frames of pictures and images appropriately hanged on the gallery wall boards, awards, artworks and objects displayed on individual stands. The montage produced by the flow of images on exhibition probably rallied to install both the titular and tutelar toga of 'Alàgbà' on Fálétí. Perhaps this also developed from a character evincing deep and cultured qualities over the last century. Qualities projectable only from such roundly home-grown dignitary. An all-round Yorùbá man from the core to the marked skin on his face.

\section{Contributions}

Adébáyọ Fálétí was Africa’s first newscaster, first stage play director, and first film editor and film librarian. His employment in 1959 made him a pioneer at the first television station in Africa, Western Nigeria Television and Broadcasting Service (WNTV/ WNBS), an institution which metamorphosed into the Nigerian Television Authority (NTA). He was Nigeria’s first Yorùbá 
presenter on both television and radio and perhaps the most respected Yorùbá Nollywood films director and actor of his era (The Adébáyọ Fálétí Foundation, 2014). In the area of translation, he flourished. He translated speeches made by former Attorney-General of the Federal Republic of Nigeria - Chief Bola Ige, former military president of Nigeria - General Ibrahim, former premier of the Western region of Nigeria Chief Obafemi Awolowo and Head, National Interim Government of Nigeria etc. from English to Yorùbá. Fálétí published a dictionary containing the formal or official use of Yorùbá names.

Bàbá Adébáyọ Fálétí translated the National Anthem into Yorùbá and was also reputed to have translated and coined Father Christmas to Baba Kérésì. He was a rigorous translator in the rich Yorùbá language culture, not only through written texts but more significantly through his strong personality and physical presence on the Nigerian cinematic stage.

In the academic environment, Bàbá Fálétí was a willing and natural collaborator within the Yorùbá cultural promotion movement both in Obafemi Awolowo University and outside the university, particularly where the artistic revolution known as the Ori Olókun movement of the 1960s in Ile-Ife was concerned.

Baba also applied his literary strength in writing books, authoring among others: Baṣọrun Gáà, İdààmú Páàdì Míkáilù, Mágùn, Wộn Rò Pé Wèrè Ni, Ogun Àwitẹlè, Ọọ Olókùn Eșin, and İjà Orogún tàbí Bí o bú mi, Ng ó bú ọ.

Furthermore, he wrote, produced and directed forty plays, including İbínú Ládélé, Àmào Amòye, Ohun tó sá pamọ, E wá kani, Baba Kérési and Oríire Bàràbà. He played a crucial part in the promotion and rise to fame of the Herbert Ogunde performance genre, having produced plays for Hubert Ogunde, Duro Ladipo, Oyin Adejobi and Kola Ogunmola for television.

\section{The Exhibition}

The art, images/pictures and artifacts exhibition is aptly themed "the thematic arts and pictorial exhibition of Alàgbà Adébáyọ Fálétí." It is designed as a free flowing or fluid interrelationship between the works of Alàgbà Fálétí and all the things found most related to his legacy, his voyage, and his name. The exhibition reveals the variety of ways in which Bàbá Fálétí as a member of society and a leader spent his life creating literary works of profound beauty and passing classical message to the larger society about the Yorùbá worldview and culture.

The exhibition venue is a gallery space of double volume and its attendant ample and interesting well-lit space. This presents adequate natural light and ventilation for the display of pictures and objects in daytime. Most of 
the works on display fulfil the visual artistic goal of education, pleasure and entertainment.

Visual art is simply 'art that is perceived by sight' (Foster 1988). Contemporary art and its exotic, experimental, and baffling manifestations perform functions in modern life as it did even in historic antecedents and early epochs.

In reviewing the exhibition, the assemblage of pictorial, artworks and objects representing the life and times of Alàgbà Adébáyọ Fálétí is assessed. This is done with a view to revealing his various life roles as a writer, poet, wordsmith, actor and public servant. The necessity of the exhibition as a tool for fulfilling a synergistic collaboration towards the promotion of Yorùbá/African culture is also analyses. Various facets of artistic practice are captured by the exhibits. A most significant part of this is the Yorùbá mode of dressing (costume). The Yorùbá worldview about dressing is reflected in proverbs. For instance, the adage iríni sí ni isoni l'ọjọ̣; also irí tí a ríni ni à ń kíni, literally translated as "the way one appears is how one will be addressed" shows that is the tradition of the Yorùbá to dress decently and neatly to be considered well dressed (Iyanda 2016).

Clothing, among the Yorùbá, is a crucial factor upon which the development of human personality is anchored. This notion implies that cap wearing is a significant aspect of Yorùbá dressing. Hence, caps are known to portray the social class, heritage, ranks and position of the wearer in Yorùbáland. For instance, the abetí ajá (dog-eared) cap is historically worn by the ruling elites in Yorùbá land. Kings and people of political standing wore caps for different occasions to identify the mood and occasion.The prevalent Yorùbá caps include abetí ajá, gọbì, filà oníde, ikòrí, àdìrọ, etc. These are also predominantly produced from three basic fabric types and colors, "gọ̣bi sányán (yellow ochre with white stripes), gọ bi ẹtù (indigo blue), gộbì àlàárì (maroon red)" (Ogunsanya 2016).

The Fálétí features the gọ bì in all the colors but in an extended hunters' fashion were displayed in the exhibition. Gội is a traditional Yorùbá cap with a round top which the wearer may choose to style and shape by folding, twisting, as he wishes. The fabric used for gọbi caps are hand woven on the traditional Yorùbá loom and referred to as așo òkè or òfì. Gộbi caps can have a small fold but rarely a long fold depending on the wearer and is usually individually hand sewn. In recent instances the gọbì and other Yorùbá traditional caps feature embroidery created as innovative designs. The custom designs are usually hand or machine embroidery works constituting flourishing industries in Yorùbáland. These are known as iṣé-onà (artistic design) which makes it very attractive to the wearer. 
The exhibition is therefore a highlight of Fálétís notion that a significant aspect of the Yorùbá culture is its regal dress sense. The Yorùbá belief that the way one dresses reflects one's status, identity and position as consistently portrayed by Fálétí in his film, is highlighted in the exhibition. The structured nature of the tradition along gender lines -- female dresses mainly accessorized with a head-tie known as gèle, and a long wrapper with a short-sleeved top, while the male's is made of long-dress in the form of a shirt almost touching the knees or even the ankles; a matching trouser often accompanying this and (filà) cap.

Fálétís predominantly indigenous cloths called aṣo òkè attained the symbolism associated with him most of his adult life because of the deliberate commitment to promoting the cultural pride. His cap, especially the gọ bi (folded over cap), is the very long type. This, however, was identified as the Ogun worshippers' or traditional Yorùbá hunters' by Alhaji Alimi. Alimi also describes several of the design elements on the garments. A few of these and the synonymous gọbi caps were among the displayed objects. The first is an aṣo òkè long flowing garment (agbádá). The embellishment or embroidery is hand woven- known as tínkó. The cap is of the òfi - the navy blue or indigo dyed indigenous woven cotton material and sewn in the Fálétí iconic hunter style. The neck embroidery on the second agbádá is known in local parlance as 'èéfiì'.

All the Fálétí caps are of the (filà ọde) hunter's style, the second flowing gown (agbada) design on display is made of the fabric popularly called lace, and the neck embroidery is called ' $20 \mathrm{U}$ '. The third is made of the fabric known as "Guinea brocade" with the neck embroidery style called 'Sulia' (Alhaji Alimi). In an interview with Baba Alhaji Alimi, Alàgbà Fálétí's mode of dressing is that of one disposed to standing out in a crowd. This artistic disposition even in traditional Yorùbá life is apparent in the various images over Fálétís developmental life stages. This personal style is probably also an influence from his Ògún deity or hunter's family line or ancestry, posits Alimi. A family value he probably also taught his children. Alimi also opines that the choice of different clothing materials in the images probably was in adopting the usage of materials available in the market at various points in his time. Garments in the pictures reflected his interest in culture (aṣo of $f$ ) without ruling out the significant influence of his profession in the media and his position as teacher and custodian of the Yorùbá language. In other pictures, the combination of his gọ bi (cap) with modern clothes signifies his loyalty to culture and a reluctant acceptance of contemporary fabric materials.

The memory of Fálétís gọ bi-topped attire will forever linger in the memories of Yorùbá culture enthusiasts, members of the University community, homes in Nigeria and the Diaspora. 
In contemporary times caps are used by politicians as a mark of distinction and a tool to carve a peculiar personality within the society. For instance, former governor of Lagos state and a national leader of the present ruling party (APC), Așiwaju Bola Tinúbú, wears a distinctive 'gộbì' cap with a particular design on it.

\section{Conclusion}

The exhibition proffers one of the most effective windows into the life and times of Alàgbà Adébáyọ Fálétí. It provides a location for interaction with personal and living possessions of the iconic writer and cultural institution called Alàgbà Fálétí. A significant part of the exhibition was to show in pictorial form how Bàbá Fálétí popularized the gọ bi cap as a Yorùbá icon. His impact was so great that the way he dons his cap sideways is now regarded as culturally iconic and a fashion statement among the Yorùbá people of Nigeria.

\section{References}

Biography of Alàgbà Adébáyọ Fálétí. Adébáyọ Fálétí Foundation. 2014. Archived from the original on $2^{\text {nd }}$ April 2019. Retrieved $3^{\text {rd }}$ April 2019.

Foster, Hal (ed). Vision and Visuality, Seattle: Bay Press, (1988).

Alhaji Alimi (age: 83). Interview. Occupation tailoring. Specialist in Yorùbá traditional wears; Idi Osan, Iwo road, Ibadan: April 2019).

Ogunsanya, Oladele. "Changing Patterns in Feeding, Dressing and Naming among Yorùbá of South-Western Nigeria since 1960," Nigerian Journal of Social Studies Vol Xvii, No. 2, ND, p.37.

Iyanda, Rabiu. "Proverb as a Moderating Potency in Yorùbá Dressing," Khazar Journal of Humanities and Social Sciences, Vol 19, No 1 (2016): 60.

Johnson, Samuel. History of the Yorùbás from the Earliest Times to the Beginning of the British Protectorate. Lagos: CSS Bookshops Ltd. 2009, pp.98-100. 


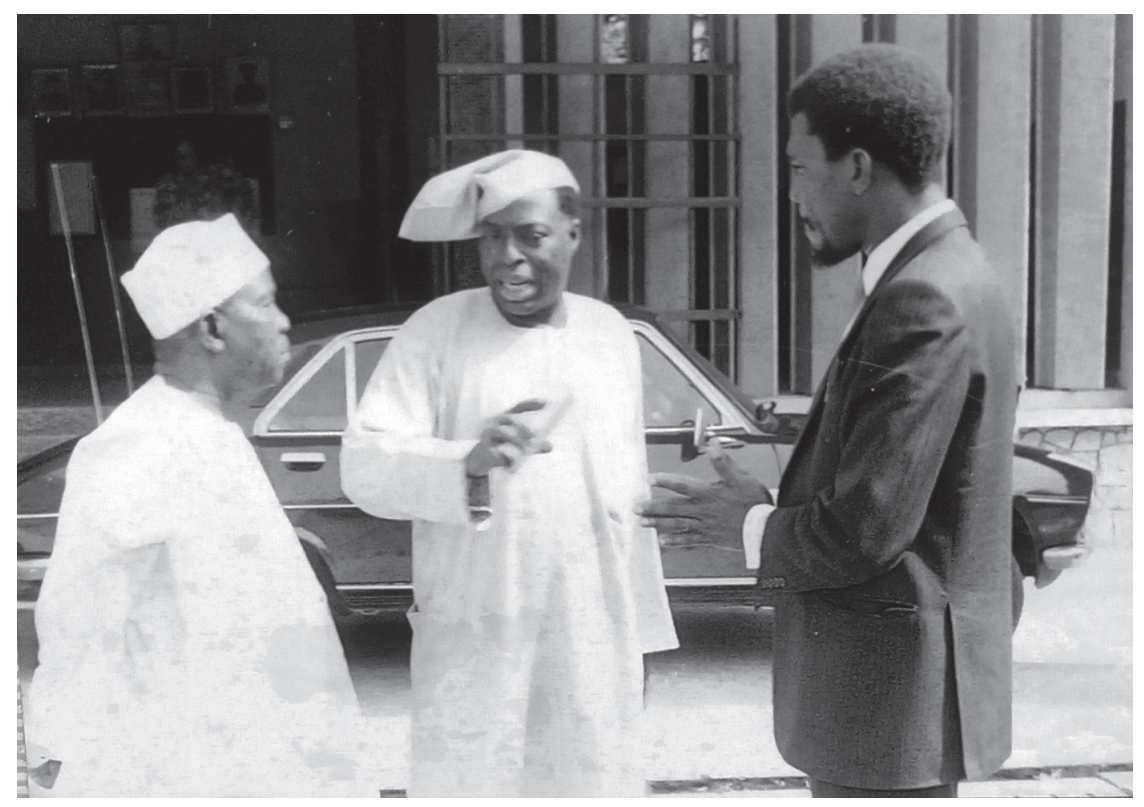

